\title{
The Wrongs of the Subaltern's Rights: a Critique on Postcolonial Diasporic Authors
}

\author{
Abida Younas \\ University of Glasgow, USA \\ Orcid id: orcid.org/oooo-0oo3-0925-3461. Email: abida.younas89@gmail.com \\ Received August 09, 2017; Revised September 14, 2017; Accepted September 18, 2017; Published September $20,2017$.
}

\begin{abstract}
My article discusses propagation of the project of orientalism in the arena of contemporary postcolonial fiction written in English by diasporic authors. In the contemporary world, the project of orientalism is no longer perpetuated by the occidentals but ironically by orientals, albeit diasporic authors, through Reorientalisation. Like orientalism, the process of Re-orientalism distorts the representation of the natives, seizes their voices and consigns them an inferior rank or in other words, the position of subalternity. Instead of giving voice to their own people, diasporic authors authenticate the project of orientalism by giving inside voices to the global world. While perpetrating the project of orientalism, they wrong the subaltern's rights as well. It is because, these writers claim to be ambassadors for their own people and foreground their issues. But instead of accentuating the plights of their own people, these writers seem to work for global capitalism, where they are required to write according to the demands of the global market. My paper aims to present a critique on those diasporic writers, who instead of resisting the orientalist agenda in their writings by highlighting the wrongs of subaltern's rights in the Third world countries, are more engaged in the project of Re-orientalism with special reference to Aslam's Maps for Lost Lovers, Adiga's The White Tiger and Abouzied's Years of the Elephant. Drawing on the theories of Gayatri Spivak, Lisa Lau, Vanessa Andreotti and Ilan Kapoor, the hypocritical role played by diasporic writers is investigated in order to emphasize that how these authors write from Eurocentric perspectives to affirm the Western hegemony over the postcolonial world even after the European decline in this part of the world.
\end{abstract}

Key Words: Subaltern, Righting Wrongs, Diasporic Writers, Re-orientalism, Eurocentric.

\section{Introduction}

The contemporary surge of narratives produced in English by diasporic authors has invited many academics and critics to categorize such literature within certain frameworks because the global publishing industry requires diasporic authors "to re-tune their voices to a key in harmony with western poetics" involving a renegotiation of 'their relationship to the world of western letters' (Maleh, 2009, p.93). They appear to deviate from the postcolonial ideology to resist and rebut colonial hegemonic forces. Instead, in accord to the demand of cultural capital they become those figures who allow the West to retain its central position. They unite to upend the discourse of orientalism which gets initiated by the West to justify its rule by presenting the orient as uncivilized or barbaric. However, caught in the global economy, these writers, rather being cultural ambassadors, become the shrewd profiteers of the global publishing industry. Unlike orientalism, which is propagated by the West, now the same project is headed by the Orientals themselves which is termed as Re-Orientalism by Lisa Lau. Re-Orientalism "imagines the

(C) AesthetixMS 2016. This Open Access article is published under a Creative Commons Attribution Non-Commercial 4.0 International License (http://creativecommons.org/licenses/by-nc/4.0/), which permits non-commercial re-use, distribution, and reproduction in any medium, provided the original work is properly cited. For citation use the DOI. For commercial re-use, please contact editor@rupkatha.com. 
production of 'the orient' by Orientals themselves - instead of by Europeans or other Westerners" (Davis, 2011, p.144). In this process, the preconceived notions about the orient are being reintroduced and reinforced by diasporic writers for global readers.

The project of Re-Orientalism is praised and congratulated by many as for them it gives voice to the subaltern. Through this project, diasporic writers mostly foreground the subaltern's issues and give them voices, yet it invites criticism from the postcolonial world. The Majority of postcolonial critics such as Graham Huggan, Lisa Lau and Pierre Bourdieu criticize Re-orientalism because it "feeds a hegemonic, postcolonial desire to consume the exotic" (Davis, 2011, p.144). By giving voices from inside, these writers perpetuate the essentialized stereotypical notion about the orient, the subalterns in particular. Postcolonial critics like Frantz Fanon and Hamid Dabashi call such diasporic writers as native informants or comprador intellectuals because these writers are supposed to provide authentic information from inside but in reality, in the words of Spivak, they provide interesting information for the first world intellectuals who are "interested in the voice of other" (1988, p.26). Spivak believes that these native informants deliberately present the subaltern as an "exotic other" (1988, p.25). Along with her critiques on native informants, Spivak condemns the knowledge being produced about the Third World because in her view it is "disinterested knowledge" loaded with power that "silences others" i.e. subalterns (1990, p.33). Instead of highlighting the issues and problems of its own people, diasporic authors feed the desire of the global cultural market in which they have to cater to the taste of the western audience. In order to meet the demands of the global market, most diasporic writers sell their creative potential to the "publishing industry that caters to Western consumer tastes" (Davis, 2011, p.145). It is because, works of art are the product of complex social process where artistic work is produced and its aesthetic worth is generated in terms of recognition and acceptance by the dominant groups, these writers deliberately incorporate those qualities in their works which are sought by the metropolitan readers and the literary mediators.

In the undertaken study, I have selected three texts from diverse postcolonial regions in order to see how different diasporic writers, belonging to different regions, deal with the issue of subalternity. My usage of diasporic authors signifies those writers who immigrate to Anglophone societies later in their life. I have selected one text from India, Aravind Adiga's The White Tiger (2008), one from Pakistan, Nadeem Aslam's The Maps for Lost Lovers (2012) and Leila Abouzeid's Year of the Elephant (1989), a text from the Arab world. The main reason for particularly selecting these three texts is that these texts take up the issue of subaltern at different levels. For example, Abouzeid shows the struggle of the subaltern in the colonial and post-colonial time periods of Morocco whereas Adiga represents striving of the subaltern in free India. Aslam, however, highlights the immigrants' issues who are the subaltern in diaspora. What unites the writings of these three authors is the fact that being diasporic writers, they use the medium of English for writing, and their relationship with their readers is mediated by the project of orientalism. Secondly, these writers, no doubt, foreground the issues of subaltern in their writings but at the same time they Re-orientalize them and make them as an exotic commodity for the western readers. In so doing, they wrong the rights of the subaltern instead of highlighting them.

\section{Theoretical Framework and Analysis}

Adiga's The White Tiger is the story of 'Balram' who belongs to the marginalized class of India. Balram is seen as a rebellious subaltern who breaks the ideology of the "rooster coop" (Adiga, 2008, p.320). It is worth mentioning here that Balram holds a low-class position as a cook in India and for generation his family has been serving those who are rich. Balram breaks that chain of 
suppression through brutal and illegal mean as "I've made it! I've broken out of the coop" (Adiga, 2008, p.320). To contradict the traditional notion of "subaltern cannot speak" (Spivak, 1988, p.28), Adiga presents the character of Balram who dares to make his voice audible and makes himself rich through criminal ways. This example uses the stereotype of the savage and brutal nature of the subaltern and shows that diasporic writers like Adiga give voice to the subalterns and foregrounds their issues at the cost of representing them morally and ethically corrupt as in the case of Balram. Secondly, these writers represent subalterns as uncivilized and nefarious who need to be swayed by the Elite or the West that can civilize them. In The White Tiger, Adiga seems to justify the rule of the West as he says that since

"the day the British left - the cages ha[ve] been let open; and the animals ha[ve] attacked and ripped each other apart and jungle law replace zoo law" (2008, p.64).

This saying of Balram clearly affirms the western hegemony over the postcolonial world. Furthermore, Balram asserts that "white skin has to be respected" (2008, p.228). These instances from text show that due to living at the western metropolitan areas, diasporic writers like Adiga work on the orientalist agenda, whereby, subalterns or in other words Easterners are shown as "white man's burden" (Pedroni, 2006, p.112) which leads to the expectation that white civilized nations are duty bound to civilize the uncivilized non-western nation. Similarly, Aslam in Maps for Lost Lovers, narrates a story of Kaukab, who is subalternized at double level. Being an immigrant in England, Kaukab is not only subaltern at societal level but at home as well. Kaukab is the true figure of those subaltern women who are doubly colonized by both: patriarchy and imperialism. Kaukab is subalternized at community level and at home because she does not adopt the Western values. Throughout the novel, Kaukab is shown as a strong advocate of traditional Pakistani values and she wants her children to adopt those values as well; but her children and her husband both have adopted the Western values and they think of Pakistani values as "harsh and disastrous" (Aslam, 2012, p.12). Whereas, Kaukab sees England as a "loathsome country" (Aslam, 2012, p.63) that has contaminated her traditional cultural ethos. These examples affirm that subalterns are made to adopt the Western values and those who reject them are shown as out casted as in the case of Kaukab who is seen as "a picture of lonliness" (Aslam, 2012, p.63). Unlike The White Tiger and Maps for Lost Lovers, in Year of The Elephant, Abouzeid tells a tale from the subaltern perspective. At the opening of the story, readers come to know that Zahra, the protagonist and the narrator of the novel, has been divorced by her husband because she prefers her traditional values. Zahra's husband, Mohammad, divorces her because she

"do[es] not eat with fork. [She] do[es] not speak French. [she] do[es] not sit with men. [She] do[es] not go out to fancy dinners" (Abouzeid, 1989, p.8).

These examples show that Zahra has been subalternized and marginalized by her own husband because she rejects the Western way of life.

The mutual theme of all the selected texts is that people, specifically subaltern in Third world countries, are required to embrace the Western ideals whereas those who refuse to adopt them are automatically subalternized. However, the point of worrying is that diasporic writers seem to applause the Western way of life and their cultural ethos and approve it as better and superior way of life as Adiga and Aslam both seem to defend the Western standards instead of their own traditions. For example, in The White Tiger, the elite class prefers foreign liquor over local such as black dog (Adiga, 2008, p.74) whereas Aslam refers to his own tradition is "like shit on [his] shoes" (2012, p.114). Given this context, these native writers, in words of Spivak, affirm the "worlding" of the West in which the Western ideals are projected over the rest part of the world as the world's interests (1990, p.1). In so doing, these writers orient people's thinking in a way that 
they accept the West's rule as something natural and significant for them. Nevertheless, this strategy of naturalization ultimately constructs the Third World as the subaltern part of the world and it legalizes the Western dominance and superiority over them. Furthermore, this strategy intensifies the gap between the First world countries and the Third world countries especially those that are once colonized by European countries like Asian and Middle Eastern countries. Spivak uses the term "epistemic violence" (as cited in Andreotti, [n.d.], p.69) for this process that fosters the unequal balance between the First world and the Third World countries. She calls it as an ideology whereby the Third World countries are required "to be civilized [and] catch up with the West" (as cited in Andreotti, [n.d.], p.7o). She asserts that this ideology prompts the under developed countries to buy "a self-contained version of the West" (as cited in Andreotti, [n.d.], p.7o). For instance, in The White Tiger, the elite class is shown as highly influenced by the West as Mr. Ashok, the son of an Indian lord, acquires Western education and marries an American woman. In the same way, in Maps for Lost Lovers, all characters seem to be fascinated by the Western values.

Spivak asserts that the colonial power alters the consciousness of subalterns and legitimizes the cultural supremacy of the West by constructing a subordinate other. She argues that the First world countries like Britain and USA reinforce the Eurocentric perspective and people from these countries are encouraged to consider themselves as masters of the world which inevitably put responsibility of helping the rest part of the world on their shoulders. Therefore, by creating and propagating their Eurocentric agenda, the Westerners legitimize the white man's burden and conflate its role over the rest part of the world. Spivak rightly deems that the desire of

"getting to know (or discursively framing) the Third World is also about getting to discipline and monitor it, to have a more manageable other: and helping the subaltern is often a reaffirmation of the social Darwinism implicit in development, in which help is framed as "the burden of the fittest" (2004, p.524).

This saying of Spivak clearly substantiates Dabashi claims that the West, for its imperial projects, needs the support of those intellectuals who can "authorize and authenticate the dominant accent" (2011, p.36). Thus, it can be suggested that these diasporic writers work at best in this regard. The phenomenon of Eurocentrism, which demands for the worldview based on the Western civilization, has bisected the world into two parts by creating the elite professional global class (it consists of people of First world countries as well as people from Third world countries who work as the Western allies) who have an access to the world's resources and they believe themselves to be human rights advocates; which in turn give them power and keep them involved in the human rights and development projects (Shemtob, [n.d.], p.2). Spivak states that this class of global elite reproduces "ethnocentric and developmentalist mythologies onto the Third World 'subalterns' that are ready to help and to develop" (as cited in Andreotti, [n.d.], p.70).

The process of epistemic violence, on one hand, authenticates the image of the West as 'civilisationally superior' (Andreotti, [n.d.], p.71) as compared to the locals or natives and at the same time, the voices of subalterns have been ignored in this process because in this case, subalterns are required to see themselves in the image of the West or to be mute spectators. For if they are given voices; their speak would not carry any authority and their voices would not be audible to the outer wider audiences. Spivak claims that between eliticism (Elite's dominance over the system) and imperialism "subject constitution and object formation" ("Can the Subaltern Speak" [n.d.], p.307) has disappeared and consequently, no space has been left for subalterns from where they can speak. For example, in Maps for Lost Lovers, Kaukab's lamentation has been ignored by her husband and by her children both. Being an immigrant, Kaukab and her family is 
already not acceptable in the mainstream society as foreigners "don't want to see them or work next to them" (Aslam, 2012, p.14). Kaukab is even called as "Paki bitch" by the whites but her grief becomes unbearable to her when her own children "refuse to speak to her" (Aslam, 2012, p.33). In the course of the novel, it has been observed that Kaukab even has given up her agency. Roberta Villalon argues that agency is the assuming authority and capacity through which an individual asserts his/her potential. Villalon in her study discusses the relationship between structures, in which the individual dwells, and his or her agency. While conducting study on Immigrants, Villalon concludes that "structures are not only constraining but also enabling resisting inequality of human agency, and that structural power not only oppresses but also generates individuals' power" (2010, p.121-122). In case of Kaukab, her surrounding structure has put the deadlock on her agency. In the course of the novel, she surrenders her agency for the sake of her children. She wants to go back to her country, Pakistan throughout her life because she considers England as a "dirty country" (Aslam, 2012, p.380) and says that "the biggest mistake of [her] life [is] coming to this country" (Aslam, 2012, p.461). She even holds her husband responsible for bringing her into an "accursed country" (Aslam, 2012, p.467); yet she refuses to go back to Pakistan for her children sake as described: "I won't move to Pakistan. What would my life be then? My children in England, me in Pakistan..." (Aslam, 2012, p.210). These illustrations clearly affirm that Kaukab has given up her agency and accepted her subaltern position at home and at society. The example of Kaukab illustrates that the dominance of European control sometimes even abducts the autonomy of subalterns. Unlike Kaukab, Zahra, in Year of The Elephant, tries to assert her agency as she manages to construct an independent life for herself on her own terms. Zahra, as mentioned previously, prefers to be divorced than to acquire the "[Western] standards" (Abouzeid, 1989, p.8). She is even accused as an "old coin fit only for the museum shelf. [Her husband's] positions in society now call for modern women" (Abouzeid, 1989, p.9); yet she refuses to be one of the modern women. In the same way, Balram asserts his agency through brutal means in order to invert his marginal position.

In case of Zahra and Balram, Mobility is also shown on their part to improve their living standards. According to John Urry, mobility improves the socioeconomic condition of individuals as it rectifies the status of Balram, but in the case of Zahra, she becomes subaltern at another level. For example, she refuses to accept the position of subalternity in her marital life and prefers to be divorced but once she got divorced, she becomes subaltern at societal level because since then she has to move around for earning sake. It would not be wrong to say that from a domestic level of subalterneity, Zahra becomes a subaltern at national level. Tamar Diana Wilson (2002) in her study discusses those subalterns who remain subaltern and at marginal status even if they change their position by travelling. She conducts her study on Mexican immigrants and states that many of them are already subalterns in their own country but once they cross the border they become subaltern at another level "where their ethnicity is suddenly underscored and their national [and] racial differences [are] marked" (Wilson, 2002, p.166). This phenomenon is very much obvious in Zahra's situation because Zahra's exploitation at home level leads her to become a subaltern at national level where along with economic exploitation; she becomes the victim of gender exploitation as well as she herself says that all this exploitation at work place is "because [she is] a woman" (Abouzeid, 1989, p.63). Moreover, in the beginning, she even has difficulty in finding a good job with a good salary so that she could bear her own expenses as she says that

"I just want a job that will earn me an honorable living, I don't care what it is. I'm not looking for a government position" (Abouzeid, 1989, p.66). 
This saying of Zahra clearly signals to the notion that subaltern has to rely on the dominant authority for their rights and thus remains deprived of it most of the time. These examples of text also show that from the domestic level of subalternization, Zahra becomes a subject of "super exploitation" and her "forward movement towards economic betterment is met by oppressive conditions" (Wilson, 2002, p.166) at national level. However, it is worth mentioning that Zahra tries to bring reform in her life by living within the status of subaltern as at every stage of her life, she asserts her agency and achieves liberty. For example, when her sister comes to pick her up; she simply refuses to go with her by saying that "[she is] not going with anybody' and '[she is] not anyone's inheritance" (Abouzeid, 1989, p.65). These illustrations highlight her strong willed nature and the assertion of her agency. Thus Zahra, unlike Kaukab, fights till the end for her rights and in the end she lives her life according to her own will. Whereas, Kaukab is shown as weak character in this regard as for the sake of her children, she seems to give up her struggle. These evidences also signal to the notion that the status and identity of subaltern are like a commodity. By commodifying the identity and stature of subalterns, diasporic writers certify them with marginal rank and show that subalterns are incapable to act for themselves. Thus, instead of liberating subalterns from their subalternity, diasporic writers deliberately make them those figures that are incapable of doing anything for their betterment or else the only way to break with subalternity is to acquire savagery as Balram does.

Rahul K. Gairola (2002) discusses subaltern's identity and identifies the identity of a subaltern as a "reflexive gift" which "stuck in a churning network of identities within the ideological constraints of society" (2002, p.308). He opines that there is an inextricable relationship between person's subjectivity and his or her agency and identity of person constructs accordingly. He claims that the subaltern's identity has "the capacity to assume the properties of the gift, it can also assume both the use value (its intrinsic potential for utility) and the exchange value (its value in a system of equivalence that is arbitrary) of the commodity" (Gairola, 2002, p.308). Thus, the identity of subaltern keeps on oscillating from use value to exchange value and vice versa according to the changing circumstances. For example, in The White Tiger, Balram sheds his use value (his identity as driver) in order to come out of the ideology of "rooster coop" and adopts the exchange value of identity to become an entrepreneur. It has been revealed that in order to shed the use value of his identity, he even tries to do all those things which Master Ashok does. He acquires the exchange value of his identity (as an entrepreneur) to cast out his subaltern identity because the condition of subalternity forces him to submit in front of his master, Mr. Ashok, and to serve him as a driver for the rest of his life. Most of time, exchange value of identity is arbitrary and a person soon comes back to his use value but in Balram's case, he has "given [him]self away" (Adiga, 2008, p.320) by casting the use value of his identity.

In Year of The Elephant, Zahra adopts the exchange value of identity with her marriage. She does whatever her husband makes her do. It has been observed that Zahra, along with her husband, has worked for the independence movement of Morocco as described that 'we (Zahra and her friend) are just beginning the real struggle for development and economic independence, the great Jihad' (Abouzeid, 1989, p.47). She even smuggles freedom fighters, guns and other information. For example, once her husband asks her to smuggle one of the detainees, whose life was in danger, in words that "you are going to smuggle him" (Abouzeid, 1989, p.46); she acts upon her husband's sayings. However, she drops the exchange value of her identity when she realizes that even after hard struggle for her husband's sake, she is still a subaltern as described 
"he glare[s] with that look that sa[ys] he would shoot me [has] he a gun in his hand --- we ha[ve] drifted far apart. A wall ha[s] seemed to rise in the intervening space. His face [is] that of a stranger, unfamiliar to me" (Abouzeid, 1989, p.54).

She realizes the fact that though she is able to achieve independence from foreigners, she cannot achieve independence from her own husband as she says to her husband that "we [fight] colonialism in their name and now you think like the colonizers!" (Abouzeid, 1989, p.54). In order to get liberty and live life according to her own will, she decides to slough off the exchange value of her identity "So I le[ave] with nothing but the clothes I ha[ve] on" (Abouzeid 1989, p.60) and opts the use value of her identity. Unlike Balram, Zahra nevertheless prefers the use value of her identity though the use value of her identity gives her subaltern status; yet she prefers her intrinsic identity than the adopted and unreal one in the form of exchange value. Unlike Balram and Zahra, the dilemma of Kaukab is complex. Kaukab, in Maps for Lost Lovers, is seen as highly distressed. Being an immigrant, living in diaspora, for Kaukab the use value of her identity is to stick strong with traditional Pakistani and religious values. In the novel, it has been perceived that Kaukab never sheds the use value of her identity (the religious Pakistani identity) though her husband and her children do not like her with her religious persona. She feels threatened for her religious persona or in other words for the use value of her identity when her own son declares that he may change his religion, Islam, as described: "she is too wounded to be diverted, even if it's she herself who has been trying to create the diversion" (Aslam, 2012, p.459). Her dilemma remains unresolved till the end of the novel as she refuses to cast off the use value (the religious persona) of her life because through her use value she feels connected to her own land, Pakistan. However, with her use value she is neither acceptable in society nor to her own children even. These instances from the selected texts illustrate that, because of their subservient position in society, subaltern's identity and its status remains oscillating to and fro between the use value and the exchange value. According to the changing circumstances, subalterns are required to shape and re-shape their identity. Due to their inferior rank, they are never given an equal status but they remain at a marginal position at the hand of the dominant one. For this reason, Spivak calls for the subalterns' status on equality basis: an equal with the dominant one.

In order to have status an equal basis, Spivak demands for the ethical encounter with the subalterns. By an ethical encounter, Spivak means that the dominant, whether they are people from the First world countries or the elite from the Third world countries, "should unlearn their privilege and learn to learn from below" (2004, p.551) means from the position of the subaltern. Kapoor (2004) also conveys the same thought and calls this process as the

"predisposition to retrace the itinerary of our prejudices and learning habits (from racism, sexism and classism to academic elitism and ethnocentrism), stop thinking of ourselves as better or fitter and unlearn dominant systems of knowledge and representation" (2004, p.641).

It is because the "impetus to always be the speaker and speak in all situations must be seen for what it is: a desire for mastery and domination" (Andreotti, [n.d.], p.75). The same view point is further continued and consolidated by Beverley, who defines this process of unlearning privilege as "to work against the grain of our interests and prejudices by contesting the authority of the academy and knowledge centers" and "continue to participate in them and to deploy that authority as teachers, researchers, administrators and theorists" (1999, p.31). In this regard, I argue that diasporic authors should work against the interest of western publishing industry and should highlight the subaltern's concern in their writings. Instead, diasporic authors, with the exception of some like Abouzeid, endorse the essentialized notion about the orients. Unlike Aslam and 
Adiga, Abouzeid seems to take the responsibility of representing subaltern's rights in her writings. Throughout her novel, she seems to highlight the concerns of subaltern and observe every situation from subaltern's perspective. She unlearns her privilege and genuinely contests the Eurocentric canon and participate in it by underscoring the subaltern's speech and their concern through her narrator, Zahra and ask non-subaltern to listen to her. In so doing, Abouzeid's writings may not enjoy the immense popularity in literary circles as compared to Aslam's and Adiga's novels but through her novel, she decenters the Eurocentric agenda by re-centering the postcolonial agenda.

Spivak also lays more emphasis on the point of learning from subaltern's perspective. She is of the view that there is a need to develop an ethical relationship with subaltern in order to minimize the violation of human rights. In her notion of "Righting Wrongs", she is of the view that in the relationship of subaltern with the dominant, subaltern's rights are always being violated by the dominant one. In this regard, learning from below would help to locate the human wrongs and it would also uncover those legacies who are the dispensers of rights. This step then would keep the check on those legacies that grant the human rights. Without learning from below, the result would be

"unexamined production of Eurocentrism, which prompts the imposition of concepts like democracy, nation, participation as universal, natural, good, unproblematic and incontestable" (Andreotti, [n.d.], p.76).

For this reason, in “Against Human Rights”, Slavoj Žižek criticizes universal human rights declaration document. In his view this document is prepared and perpetrated by the West. The idea of human rights is essentially a Western notion which is imposed on other societies as "culturally hegemonic and potentially destabilizing" (cited in Shemtob, [n.d.], p.2). He, thus, questions human rights of Third World countries in words that "what the human right of Third World suffering victims effectively means today, in the predominant [Western] discourse" (Žižek, 2005, p.128). Moreover, by presenting his discontent regarding universal human rights discourse in his studies "Against Human Rights" he states that "human rights advocates may believe their cause to be noble, they are actually modern emissaries of the white man's burden' (cited in Shemteb, [n.d.], p.2). These wrongs thus need to be addressed in order to scrutinize the human rights discourse for otherwise Subalterns would remain deprived of their basic rights.

Given this context, I believe that there is a need to foreground the wrongs of subalterns' right in order to expose the vertical relationship between the dominant and those who are at subaltern position. In this vertical relationship, the dominant remains at the top whereas, subalterns occupy the lower position. The upper position makes the dominant as the dispenser of rights which gives them an edge to violate it for their own purpose. To deconstruct this vertical relationship, I believe that diasporic writers should take the responsibility of representing the wrongs of subaltern's rights to uncover the violation of human rights and injustices in the system. I strongly concur with the Spivak's notion of Righting Wrong in this regard. Spivak is right in her assertion that

"human right is not only about having or claiming a right or a set of rights; it is also about righting wrongs, about being the dispenser of these rights" (2004, p.523-24).

Thus, it would not be wrong if diasporic writers work to unveil the wrongs of the subaltern's rights. By showing only the dark, miserable and corrupt conditions of their own people, diasporic writers legitimize the colonial subjugation. In so doing, these diasporic writers feed the hegemonic desire of consuming the exotic East and strengthen the orientalism discourse 
by Re-Orientalizing them. Secondly, by using the trope of orientalism, these writers buttress the Eurocentric Worldview in which the West still occupies the dominant hold. In any case, however, orientalism has survived by creating two binary poles where, at one side, the dominants reside who are the advocates of human rights and at other pole subalterns dwell in. From this perspective, it can be argued that many diasporic authors, instead of being a voice for their own people, with their project of Re-Orientalism fail "the subaltern as a means for speaking in a truly original or authentic voice" (Lau \& Mendes, 2011, p.20). Diasporic writers, who are considered as the ambassador of one's country, do not raise voices for the rights of their own people to avoid being ignored by reviewers and publishers.

\section{Conclusion}

To conclude, I would sum up my debate with Spivak's suggestion that there is a need of such an educational approach that could enable human beings to learn other's values and differences. There is a need to reconstruct the world views that would rely on an ethical relationship of East with the West or the elite with the subaltern and vice versa. In this regard, diasporic writers along with other authorities such as governmental bodies should work to establish the relationship based on relational dialects. The relational dialect is a philosophical concept that refers to maintain the relationship even with varying differences, tensions and contradictions. Baxter claims that relationship built on "relational dialects" might have conflicts from both sides yet it would have totality as well (2004, p.183). Keeping in view this, the dominant and the subaltern needs to have relationship based on relational dialects. It may have contradiction but in this way the interaction and communication of the dominant and the subaltern can get initiated.

\section{Acknowledgement}

I would like to thank Dr. Saiyma Aslam, Dr. Aroosa Kanwal and Ms. Amal Sayyid for their valuable suggestions.

\section{Work Cited}

Abouzeid, Leila. (1989). Year of the Elephant. [N.p.]:[n.p.].

Adiga, Aravind. (2008). The White Tiger. India: HarperCollins Publishers.

Andreotti, Vanessa. [n.d.]. An Ethical Engagement With Other: Spivak's Ideas on Education. Critical Literacy: Theories and Practice, 1(1), 69-79.

Aslam, Nadeem. (2004). Maps for Lost Lovers. India: Random House India.

Baxter, Leslie. A. (2004). A Tale of Two Voices: Relational Dialects Theory. The Journal of Family Communication, 4(3\& 4), 181-192.

Beverley, John. (1999). Subalternity and Representation: Arguments in Cultural Theory. Durham: Duke University Press.

Dabashi, Hamid. (2011). Brown Skin White Mask. London: Pluto Press.

Davis, Ann Marie L. [n.d.]. Re-Orientalism and South Asian Identity Politics: The Oriental Other Within. Journal of International Global Studies, 144-148. 
Gairola, Rahul. (2002). Burning With Shame: Desire and South Asian Patriarchy, from Gayatri Spivak's "Can the Subaltern Speak?" to Deepa Mehta's "Fire". Comparative Literature, 54(4), 307-324.

Kapoor, Ilan. (2004). Hyper-Self Reflexive Development? Spivak on Representing the Third World 'Other'. Third World Quarterly, 4(25), 627-47.

Lau, Lisa. (2011). Re-Orientalism in Contemporary Indian Writing in English. In Lisa Lau \& Cristina Mendes (Eds.), Re-Orietalism and South Asian Identity Politics: The Oriental Other Within (15-39). New York: Routledge.

Maleh, L. A. (2009). Arab Voices in Diaspora: Critical Perspectives on Anglophone Arab Literature. New York: Rodopi.

Pedroni, Thomas. C. (2006). Can The Subaltern Act? African American Involvement in Educational Voucher Plans. In Michael W. Apple \& Kristen L. Buras (Eds.), The Subaltern Speak: Curriculum, Power And Educational Struggles (95-120). New York: Routledge.

Shemtob, Zachary. [n.d.]. Human Rights and Wrongs: A Critical Overview of Contemporary Human Rights Skepticism, 1-17.

Spivak, Gayatri Chakravorty. (1988). Can The Subaltern Speak?. In Cary Nelson \& Lawrence Grossberg (Eds.), Marxism and The Interpretation of Culture (24-28). London: Macmillan.

Spivak, Gayatri Chakravorty. (2004). Righting Wrongs. The South Atlantic Quarterly, 103(2/3), 523-581.

Spivak, Gayatri Chakravorty. (1990). The Post-colonial Critic: Interviews, Strategies, Dialogues. Ed. Sarah Harasym. New York: Routledge.

Villalon, Roberta. (2010). Violence Against Latina Immigrants: Citizenship, Inequality and Community. New York: New York Press.

Wilson, Tamar Diana. (2002). Counterhegemony: Undocumented Mexican Immigrants Crossing the Border. Urban Anthropology and Studies of Cultural Systems and World Economic. 31(2), 163-197.

Žižek, Slavoj. (2005). Against Human Rights. New Left Review. 34, 115-131.

Abida Younas, is a doctoral researcher at University of Glasgow, UK. Her major interest lies in researching newer possibilities and she likes to explore new areas related to the current situation of Postcolonial countries (South Asian and Middle Eastern Countries) and its effect on the contemporary literature. Along with publication in different journals, she has also presented seven papers at different International and National conferences held at Pakistan, UK and USA. 